\title{
Namesto uvoda
}

Igor Ž. Žagar

Devetega in 10. septembra 2020 je v prostorih Znanstveno raziskovalnega centra SAZU potekala 5. nacionalna znanstvena konferenca »Raziskovanje v vzgoji in izobraževanju«. Na konferenci, katere tema je bila Medsebojni vpliv raziskovanja in prakse, je bilo tokrat, zaradi omejitev povezanih z epidemijo, predstavljenih le 51 prispevkov, odvile pa so se tudi 3 panelne razprave.

Večina avtoric in avtorjev je svoje konferenčne prispevke razširila $v$ znanstvene članke, 22 jih je uspešno prestalo dvojno slepi recenzentski postopek, in te najdete v pričujoči monografiji. Članki posegajo na vsa tematska področja konference, od učenja in poučevanja, izobraževalnih politik in zagotavljanja kakovosti, pa vse do socialnih in čustvenih vidikov vzgoje in izobraževanja ter vloge IKT. Močan pečat je na konferenčnih prispevkih pustil epidemični vpliv na vzgojo in izobraževanje, ki ga odsevajo tudi prispevki te monografije.

Želim vam prijetno in, upam, navdihujoče branje!

Ljubljana, avgust 2021

prof. dr. Igor Ž. Žagar, predsednik Programskega odbora 